\title{
Practice or preach? The actual purchasing behavior of responsible consumers in mass market*
}

\author{
Matteo Pedrin ${ }^{* *}$ Laura Maria FerRI $I^{* *}$
}

\begin{abstract}
Purpose of the paper: To measure the gap between the propensity towards responsible consumerism and the actual behavior of Italian consumers in real settings.

Methodology: We explored the responsible consumerism propensity-behavior gap, taking into consideration a sample of 5.098 Italian consumers and analyzing the most purchased products by the group of 766 consumers that declared a high propensity towards responsible consumerism in the initial part of the survey.

Findings: Results confirm the existence of a responsible propensity-behavior gap in real scenarios, since only $37,2 \%$ of mostly-purchased products by responsible consumers has a social or environmental label. The analysis of the rationale highlights that purchasing decisions are mainly based on environmental and health-related values, whereas strictly socially-oriented characteristics receive limited attention.

Research limits: The study collected data only on Italian consumers and therefore did not allow us to understand the impact of different national cultures on consumers.

Practical implications: Since products with pure social or environmental contents target only well-informed consumers, managers should increase consumers' knowledge around the social and environmental contents of products. If managers want to target a larger share of market, they should develop products that exploit social/environmental characteristics to enhance performance related to traditional attributes.

Originality of the paper: The study is one of the first to consider both the propensity and actual behavior of consumers. Second, while previous researches had studied behaviors in experimental, hypothetical or ad-hoc setting, this one is the first that investigates behavior by using data on purchases in real settings regardless of the store.
\end{abstract}

Key words: corporate social responsibility; sustainability; segmentation; positioning \& targeting; marketing strategy

* The paper is the result of the collaboration of the authors who are jointly responsible. The text is attributed as follows: paragrafhe 2 and 4 to Matteo Pedrini; paragrafhe 1 and 3 to Laura Maria Ferri; paragrafhe 5 to both the authors equally.

** Assistant Professor of Business Strategy - Università Cattolica del Sacro Cuore e-mail: matteo.pedrini@unicatt.it

**** Assistant Professor of Business Management - Università Cattolica del Sacro Cuore e-mail: laura.ferri@unicatt.it 


\section{Introduction}

Studies on the relationship between efforts of corporations regarding social and environmental issues and economic performances have investigated the relation between short term and long term performance (Sciarelli, 2005; Caselli, 2005; Pascucci, 2011), discussing the positive influence business engagement in social and/or environmental initiatives can have on consumers' perceptions (Brown and Dacin, 1997); on the other hand, they have considered the negative effects determined by ethical abuses (Steenhut e Van Kenhove, 2006).

Over the years, the field of research on responsible consumers moved/has shifted from the idea that consumers pay attention exclusively to social issues (Webster, 1975), to the idea that consumers only take environmental implications into consideration (Prothero, 1990; Vandermerwe and Oliffe, 1990; Peattie, 1995; Schlegelmilch et al., 1996; Menon and Menon, 1997; Fuller, 1999). However, an increasing number of authors has recognized the convergence of social and environmental orientation into a unique construct (Engel and Blackwell, 1982; Roberts, 1996; Strong, 1996; Shaw and Newholm, 2002; Newholm and Shaw, 2007). Referring to Shaw and Newholm (2002, p. 168) such convergence can be described as 'the inextricable link between consumption and ethical problems, such as environmental degeneration and fairness in world trade'.

Research has pointed out that non-utilitarian motives referred to hedonistic satisfaction-seeking behavior are steadily integrating traditional utilitarian product attributes such as price and quality (Arnold and Reynolds 2003; De Pelsmacker et al., 2005). Studies have sustained the existence of consumers that are willing to reward social and/or environmental aspects in their buying decisions (Vitell, 2003). This is generally known as responsible consumerism propensity (RCP), defined as a/the "consumer's personal orientation to consider the social and environmental implications related to their purchasing decisions" (Pedrini and Ferri, 2014, p. 2).

Although the topic has been the object of a broad range of studies (Anderson and Cunningham, 1972; Hunt and Vitell, 1986; Pol, 1986; Roberts, 1995), there is still a general need to foster research in the field since results have been mixed and contradictory and unsuccessful in providing clear understanding of responsible consumers (Schlegelmilch et al., 1996; Wagner, 1997; Straughan and Roberts, 1999; McDonald et al., 2006).

Studies reveal a difference between the percentage of adults who claim to be aware of social issues and that of those who actually purchase social products (Krier, 2007; Nicholls and Lee, 2006). The existence of such a gap has been demonstrated by theoretical works and research projects carried out in experimental settings (Bjørner et al., 2004; Page and Fearn, 2005), but there is still a dearth of studies investigating consumers' behavior in everyday life and settings.

Starting from these considerations the present study addresses the RCP-behavior gap in a real setting and is different from previous studies on the topic for three main reasons. First, previous work had mainly explored consumers' social and environmental orientation based on their declared propensity, while research on 
actual behaviors is still weak. This study considers both propensity and behavior, therefore contributing to understand if the gap is determined by weaknesses in survey methodology or by an actual dichotomy in consumers' decision-making. Second, while previous researches had studied behaviors in experimental, hypothetical or ad-hoc settings, this is the first to investigate behavior by using data on purchases in real settings regardless of the store. Thus it complements other works, considering consumers' choices and behaviors within the multiple attributes of their everyday life, and it helps to verify the relationships between social, environmental and traditional criteria. Third, the research also deepens the study of the propensity-behavior gap by analyzing the rationales behind responsible consumption.

In order to make these contributions significant, the research selected customers with a high-declared responsible consumerism propensity (RCP) among 5.098 Italian consumers and analyzed the basket of their mostly-purchased products in 2008. To do that, the survey was performed in partnership with AC Nielsen, one of the most important analysts of market behavior and dynamics worldwide.

\section{The RCP-Behavior gap}

While the potential RCP-behavior gap notion has gained increasing attention from both academics and practitioners, research on its relevance in market behavior has shown different evidences. A group of studies demonstrated that consumers who claim to pay attention to social issues in their consumption decisions (Rode et al., 2008). Conversely, other studies suggested that consumers do not "practice what they preach" so a gap between the importance they attribute to social and/or environmental issues and the way they actually behave when buying products (Page and Fearn, 2005) was observed. This discussion leads to the conclusion that a misalignment of buying practices and social and/or environmental intentions characterizes consumers' behavior (McGregor, 2006).

The dichotomy between propensity and behavior may be partially ascribed to difficulties in survey methodologies and instruments. While explored issues are socially acceptable in theory, they are difficult to measure in practice. For instance, some researches tried to estimate the overall willingness of consumers to pay for goods or services with a social or environmental content, but they took hypothetical contexts into consideration, thus representing behavior that may or may not be confirmed in real situations and may not be generalized to market behavior (Bjørner et al., 2004). Studies in real situations were performed to focus on the RCP-behavior gap, but they were carried out in a limited number of stores.

The most recent developments around the concept of responsible consumerism show an increasing interest in the rationale behind responsible consumers' decisionmaking (Megicks et al., 2008). Since buying decisions express a number of different consumers' values and intentions and refer to different concepts of morality (Caruana, 2007), rationale is intended as the prevailing reason that determines the 
choice of specific products or services. The identification of rationales behind purchasing decisions allows the development of appropriate targeting and positioning strategies of responsible products (Megicks et al., 2008; Perrini and Tencati, 2008). More specifically, two main rationales can be identified: a political interest or self-interest.

The political interest emerged as the consequence of consumers' rising awareness of their potential power to affect corporate behaviors through their buying decisions. It was initially translated into sanctioning or punishing actions for irresponsible companies, such as non-buying or boycotting campaigns (Nebenzahl et al., 2001). It is the case, for instance, of the boycotts against Nike and other apparel companies because of their labor-related abuses (Locke, 2003) or those of Nestlé products because of the scandals on infant milk (Garrett, 1987). Lately, consumers also became conscious of the possibility to affect companies' behavior through rewarding behaviors (Uusitalo and Oksanen, 2004). In this sense, the preference for products with a recognizable social and/or environmental content expresses their willingness to encourage corporate commitment to social and environmental management (De Pelsmacker et al., 2005; Bennet, 2004, Bjørner et al., 2004). Both behaviors have been referred to as political consumerism (Micheletti and Stolle, 2009), which identifies "the choice of producers and products with the aim of changing ethically or politically objectionable institutional or market practices" (Micheletti and Stolle, 2005, p. 470).

The second rationale has been referred to as self-care consumption and described as more individual-centered because consumers' choices are based on considerations around products (Nicholls, 2004) and socially or environmentally responsible products are perceived as superior to traditional ones because of such characteristics (Varul and Wilson-Kovacs, 2008). In this case, consumers' purchasing decisions are made based on criteria related to aesthetic, wellbeing and health care judgments (Moorman and Matulich, 1993). Examples can be found in practices related to the consumption of ecological food (i.e. biological product) or the usage of organic material in the textile sector (i.e. organic cotton), that are determined by the will to promote the reduction of chemical fertilizers, dyes and treatments. Although buying decisions are mainly determined by personal needs of health and body protection in this case, consumers are nevertheless aware of their power to contribute to the promotion of new, more sustainable lifestyles in favor of long-term social and/or environmental progress.

\section{Hypotheses of research}

Based on the above-discussed backdrop, the present work addresses the propensity-behavior gap and rationales of responsible consumers by investigating their actual choice in real settings. In particular, the study aims to verify the following hypotheses. 
First of all, the data collection and analysis will allow further exploration of the suggested - but still unclear - consumers' different orientation towards social and environmental products. More specifically, findings are expected to confirm the following hypothesis:

HP1: the RCP-behavior gap is more evident for socially-oriented products rather than environmental ones.

Second, the analysis will explore the RCP-behavior gap with regards to the rationale that moves consumers' decision making. In this sense, the analysis is aimed at facilitating the understanding of whether the misalignment between propensity and behavior is related more to political or self-care motives. In particular, the following hypothesis will be verified:

HP2: the RCP-behavior gap is narrower when consumers are moved by self-care rationale.

\section{Methodology}

In order to confirm (or deny) these two hypotheses, research was conducted through three phases. The first phase consisted in a questionnaire submitted to the entire panel of consumers of the Home Scan Panel at AC Nielsen. The objective was to identify clusters of consumers based on their propensity towards social and environmental aspects in purchasing decision-making. The second step only took considered the cluster of consumers with the highest propensity - named "Responsible Consumers" - and analyzed the goods they actually purchased in 2008 in their real setting. Thus, this phase verified whether the high propensity towards social and environmental products was matched by the actual behavior of responsible consumers. The third and last part selected the most purchased goods by responsible consumers and analyzed their social and environmental features through specific labels and information on packaging.

\subsection{The measurement of $R C P$}

The questionnaire used in the first phase consisted of two parts: the former collected data about the relevance given to both social and/or environmental content of products and firm responsible behaviors; the latter gathered data on consumers' declared behavior towards products and firms on the basis of their social and/or environmental characteristics. To gather information, a telephone survey was conducted on a sample of 12.000 Italian consumers over 14 years of age during the summer of 2008. Participants were part of the Home Scan Panel headed by AC Nielsen, a monitoring panel of consumerism that involves randomly chosen people in Italy and is composed to represent the Italian population. The response rate was 
$42,5 \%(n=5.098)$ and the final sample is representative of the demographical distribution of the Italian population (Istat, 2009).

To measure the level of RCP of each consumer, an exploratory factor analysis was run out by using Keiser's criterion and experimenting with a different number of factors. The variables referred to the questions submitted to consumers through the above-mentioned telephone survey converged into a single factor. We first checked for multicollinarity among variables, looking at the determinant of the correlation matrix $(0,84)$ to make sure it was greater than the generally accepted value of 0,000001 . Then we conducted Bartlett's test of sphericity $(p<0,05)$ and checked for the Kaiser, Mayer and Olkin $(0,774)$. We verified whether the factor analysis would have been better with two or more factors, and the analysis of the Eigenvalue plot confirmed that the best option was to have only one component (Tabachnick and Fidell, 2008). The adoption of one factor solution in the analysis is consistent with earlier literature which underlined that factors with Eigenvalues lower than 1 must not be considered (Gorsuch, 1983).

To assess the validity of the scale we conducted a confirmatory factor analysis with maximum likelihood estimation. The final model displays acceptable fit indices $(\chi 2=123,24 ; \mathrm{DF}=13 ; \mathrm{p}=0,01 ; \mathrm{GFI}=0,91 ; \mathrm{CFI}=0,98 ; \mathrm{RSMEA}=0,07)$, that meet the recommended levels for a model with good fit (Hair et al. 2006). This indicates that the developed RCP scale is valid. Table 1 shows the loading values of RCP including both the orientation of consumers toward social and/or environmental information and the integration of these dimensions in decision making processes.

A cluster analysis was used to categorize consumers and create subgroups with minimized within-group variation and maximized between-group variation (Hair and Black, 2000). A two-stage clustering approach was then used (Punj and Stewart, 1983). The first stage consisted in determining the number of groups of consumers and applying hierarchical analyses by means of Wards' method and squared Euclidean distances (Malhotra, 1996); we found that the number of clusters was equal to 4 . The second stage involves the non-hierarchical K-Means analysis based on the number discovered during the hierarchical clustering procedure in order to assign consumers into clusters. A discriminate analysis was used to determine whether clusters could be distinguished based upon the demographical characteristics of their components. Since the demographical variable was categorical, the differences between genders were analyzed through a t-test, while the impact of other variables was explored using a "one-way between group analysis of variance" (ANOVA).

An analysis of the Kolmogorov-Smirnov (K-S Lilliefors) and the Shapiro-Wilk normality tests show that the distribution of variables among clusters respect the assumption of normal distribution. In addition, for each variable, Levene's test for the homogeneity of variances was conducted and it was not significant at a level of 0,05 (Cohen, 1988).

To test the mean differences among the groups the Tukey HSD was calculated using a post-hoc comparison. To ensure the readability of the article and to allow the 
reader to understand the reliability of our analysis, the results of post-hoc tests are presented in the tables included in appendix A.

Tab. 1: The structure of the RCP factor

\begin{tabular}{|c|c|c|}
\hline $\begin{array}{l}\text { Behavior } \\
\text { Towards }\end{array}$ & Items & Loading \\
\hline \multirow[t]{5}{*}{ Information } & $\begin{array}{l}\text { 1. I pay attention to information on social behavior of firms when someone } \\
\text { speaks about it }\end{array}$ & 0,516 \\
\hline & 2. I know products/services that give a portion of the price to social causes & 0,516 \\
\hline & 3. I don't know firms that I think are responsible & $-0,421$ \\
\hline & 4. I don't know firms that I think are not responsible & $-0,454$ \\
\hline & 5. I don't care about information on the firms' social behavior & $-0,659$ \\
\hline \multirow[t]{4}{*}{ Products } & 6. I bought fair trade products in the last 12 months & 0,550 \\
\hline & $\begin{array}{l}\text { 7. I bought products/services that give a portion of the price to social } \\
\text { causes }\end{array}$ & 0,578 \\
\hline & $\begin{array}{l}\text { 8. I think firms propose responsible products but only to increase their } \\
\text { prices }\end{array}$ & $-0,430$ \\
\hline & 9. I think the cost of life today is too high to buy responsible products & $-0,456$ \\
\hline \multirow[t]{5}{*}{ Firms } & $\begin{array}{l}\text { 10. I do not change my behavior with the firms that I think have bad } \\
\text { social or environmental behaviour }\end{array}$ & $-0,481$ \\
\hline & $\begin{array}{l}\text { 11. I recommend family and friends to purchase the products of firms that I } \\
\text { think are socially responsible }\end{array}$ & 0,462 \\
\hline & 12. I try to purchase products/services from responsible firms & 0,620 \\
\hline & $\begin{array}{l}\text { 13. I speak poorly with family and friends about firms that I think are not } \\
\text { socially responsible }\end{array}$ & 0,456 \\
\hline & $\begin{array}{l}\text { 14. I try not to purchase the products/services of firms that I think are not } \\
\text { responsible }\end{array}$ & 0,580 \\
\hline
\end{tabular}

Source: Authors' Own Elaboration

\subsection{The analysis of the actual purchases of Responsible Consumers}

The second phase analyzed the actual purchasing choices of the previously identified responsible consumers by using the Nielsen database of products purchased by each consumer. As members of the Home Scan panel of AC Nielsen, all consumers in the sample had to register the barcodes of all products they had purchased during 2008, and send them to the AC Nielsen database on a daily basis. Therefore, the database includes all the data on products that were really purchased by consumers in their everyday lives.

To analyze the RCP-behavior gap, we focused on products that were bought by responsible consumers in a quantity that was almost higher than the mean plus standard deviation observed in the other groups of consumers. A total number of 344 products (intended as articles) were identified as the "most purchased products" by responsible consumers and taken as an indicator of differences in purchasing behavior among responsible and other groups of consumers. These products were classified as either socially or environmentally oriented in order to investigate whether consumers' actual choices mainly preferred products with such characteristics, thus matching the declared superior propensity. In order to do that, the packaging of each of the most purchased products was then analyzed to identify labels on social and/or environmental content. The decision to consider packaging 
information was based on the intention to narrow the analysis to products, which contained information on social and environmental characteristics that was available to all consumers.

As Table 2 shows, seven different labels were considered: (1) biological label, which means that herbicides, pesticides, non-natural ingredients, or genetically modified ingredients were not used (De Pelsmacker et al., 2005); (2) cause-related campaign label, which states that part of the price of the product will be devoted to support a social campaign (DiNitto, 1989); (3) responsible supply chain label, which means that social and/or environmental issues are integrated in the systemic coordination of key inter-organizational business processes (Carter and Dale, 2008); (4) diet nutritional label, which means that the product is intended to benefit personal health through its limited caloric weight (Klopp and McDonald, 1981); (5) ecological packaging label, which states that the packaging was made to be reduced, recovered, reused and recycled (Brody and Marsh, 1997); (6) ecological label, which outlines that the product is realized in respect of the natural environment through reduced usage and emission of resources (West, 1995); (7) fair trade label, which means that the product is manufactured and distributed in respect of fair trade principles (Goldsmith and Mander, 1996). The analysis also searched for other labels that had not been considered in the abovementioned classification, but no others were found.

Tab. 2: Considered labels

\begin{tabular}{|c|c|}
\hline Label & Description \\
\hline Biological & $\begin{array}{l}\text { Without herbicides, non-natural ingredients, or genetically modified } \\
\text { ingredients (De Pelsmacker et al., 2005). }\end{array}$ \\
\hline $\begin{array}{l}\text { Cause-related } \\
\text { campaign }\end{array}$ & $\begin{array}{l}\text { With part of the price devoted to support a social campaign (DiNitto, } \\
\text { 1989). }\end{array}$ \\
\hline Responsible & Social and/or environmental issues are integrated in the systemic \\
\hline supply chain & $\begin{array}{l}\text { coordination of key inter-organizational business processes (Carter } \\
\text { and Dale, 2008). }\end{array}$ \\
\hline Diet nutritional & $\begin{array}{l}\text { Limited caloric weight to benefit personal health (Klopp and } \\
\text { McDonald, 1981). }\end{array}$ \\
\hline $\begin{array}{l}\text { Ecological } \\
\text { packaging }\end{array}$ & $\begin{array}{l}\text { Packaging realized to be reduced, recovered, reused and recycled } \\
\text { (Brody and Marsh, 1997). }\end{array}$ \\
\hline Ecological & $\begin{array}{l}\text { Manufactured in respect of the natural environment through reduced } \\
\text { usage and emission of resources (West, 1995). }\end{array}$ \\
\hline Fair trade & $\begin{array}{l}\text { Manufactured and distributed in respect of fair trade principles } \\
\text { (Goldsmith and Mander, 1996). }\end{array}$ \\
\hline
\end{tabular}

Source: Authors' Own Elaborations

\subsection{The analysis of the rationales}

The third step aimed at highlighting the rationale behind the purchasing choices of responsible consumers and considered only products with a social and/or environmental label among those most often purchased by responsible consumers. In order to respond to the second research question based on previous literature 
review, products were related to and classified under the two main rationales. More specifically, products were divided between those related to a self-care interest (biological, diet nutritional) and those with a political content (cause-related marketing campaign, responsible supply chain, ecological packaging, ecological product, fair trade). A descriptive analysis was run to reveal which of the two rationales had primarily determined the choice of products by responsible consumers.

\section{Results}

Using clusters analysis, four groups of consumers were identified based on their declared RCP. Table 3 presents the descriptive statistics of the RCP and demographical characteristics of consumers in each cluster.

Tab. 3: Clusters based on RCP

\begin{tabular}{|c|c|c|c|c|c|c|}
\hline \multirow[b]{2}{*}{ Variables } & \multirow[b]{2}{*}{$\begin{array}{c}\text { Total } \\
n=5,098\end{array}$} & \multicolumn{4}{|c|}{ Clusters } & \multirow[b]{2}{*}{ Differences } \\
\hline & & $\begin{array}{c}\text { Indifferent } \\
\mathrm{n}=911\end{array}$ & $\begin{array}{c}\text { Circumspect } \\
n=1,529\end{array}$ & $\begin{array}{c}\text { Moderate } \\
\mathrm{n}=1,892\end{array}$ & $\begin{array}{c}\text { Responsible } \\
n=766\end{array}$ & \\
\hline RCP & & & & & & \\
\hline Mean & 0,049 & $-0,411$ & $-0,099$ & 0,208 & 0,499 & \\
\hline Std. Dev. & 0,306 & 0,116 & 0,087 & 0,095 & 0,091 & \\
\hline Gender & & & & & & $t(5.098)=1.907$ \\
\hline Females & $51,1 \%$ & $47,6 \%$ & $52,3 \%$ & $51,0 \%$ & $53,3 \%$ & $\mathrm{p}=0,057$ \\
\hline Males & $48,9 \%$ & $52,4 \%$ & $47,7 \%$ & $49,0 \%$ & $46,7 \%$ & \\
\hline Age & & & & & & $F(5.094)=23.664$ \\
\hline $14-19$ & $4,6 \%$ & $11,3 \%$ & $5,5 \%$ & $2,0 \%$ & $0,9 \%$ & $\mathrm{p}=0.000$ \\
\hline $20-24$ & $3,5 \%$ & $6,5 \%$ & $3,9 \%$ & $2,4 \%$ & $2,1 \%$ & \\
\hline $25-34$ & $14,1 \%$ & $15,9 \%$ & $14,3 \%$ & $14,2 \%$ & $11,6 \%$ & \\
\hline $35-44$ & $29,6 \%$ & $24,6 \%$ & $29,2 \%$ & $31,8 \%$ & $30,9 \%$ & \\
\hline $45-54$ & $17,5 \%$ & $12,3 \%$ & $16,4 \%$ & $18,8 \%$ & $22,5 \%$ & \\
\hline $55-64$ & $14,9 \%$ & $13,0 \%$ & $14,5 \%$ & $15,1 \%$ & $17,6 \%$ & \\
\hline$>65$ & $15,8 \%$ & $16,5 \%$ & $16,3 \%$ & $15,8 \%$ & $14,4 \%$ & \\
\hline Income & & & & & & $F(5.094)=38.588$ \\
\hline Low & $16,4 \%$ & $23,7 \%$ & $17,7 \%$ & $15,0 \%$ & $8,7 \%$ & $p=0.000$ \\
\hline Low-Medium & $28,7 \%$ & $31,3 \%$ & $29,8 \%$ & $28,0 \%$ & $24,9 \%$ & \\
\hline Medium-High & $35,3 \%$ & $31,0 \%$ & $34,5 \%$ & $36,4 \%$ & $39,3 \%$ & \\
\hline High & $19,6 \%$ & $14,1 \%$ & $18,0 \%$ & $20,6 \%$ & $27,0 \%$ & \\
\hline Educational level & & & & & & $F(5.094)=12.073$ \\
\hline Minimum level & $65,8 \%$ & $80,4 \%$ & $70,6 \%$ & $57,1 \%$ & $49,0 \%$ & $\mathrm{p}=0.023$ \\
\hline High school & $26,1 \%$ & $15,9 \%$ & $22,5 \%$ & $32,7 \%$ & $36,9 \%$ & \\
\hline Graduate & $8,1 \%$ & $3,7 \%$ & $6,9 \%$ & $10,2 \%$ & $14,1 \%$ & \\
\hline
\end{tabular}

Source: Authors' Own Elaborations

The first cluster, named "indifferent", includes all consumers with a clear negative $\mathrm{RCP}(\mathrm{M}=-0,411 ; \mathrm{SD}=0,116 ; \mathrm{n}=911)$. The second includes "circumspect" consumers with a RCP that is close to zero who have not declared a clear (either positive or negative) orientation towards social and environmental issues in their consumption process $(\mathrm{M}=-0,099 ; \mathrm{SD}=0,087 ; \mathrm{n}=1.529)$. The third cluster involves "moderate" consumers, who declared a positive but fair RCP, characterized by a 
temperate interest in social and environmental characteristics $(M=0,208 ; \mathrm{SD}=0,095$; $\mathrm{n}=1.892$ ). The last cluster included the "responsible" consumers. It includes consumers with the highest RCP who are highly aware of social and environmental issues $(\mathrm{M}=0,499 ; \mathrm{SD}=0,091 ; \mathrm{n}=766)$. The cluster of responsible consumers is the least numerous, involving $15,0 \%$ of the consumers.

Before analyzing the products bought by responsible consumers, the demographical characteristics of responsible consumers were compared to those of other clusters by using the t-test and the ANOVA test. As regards the gender an independent sample two-tailed t-test was conducted and results showed a weak difference in scores between men $(\mathrm{M}=0,041 ; \mathrm{SD}=0,310)$ and women $(\mathrm{M}=0,058$; $\mathrm{SD}=0,302), \mathrm{t}(5.098)=1,907, \mathrm{p}=0,057$. The other demographical variables are significant for consumers' identification in responsible clusters. Responsible consumers are mainly between 35 and 64 years old, have a high income and a high educational level. Based on the seven analyzed ranges, the age of consumers is statistically different in the responsible cluster at the $\mathrm{p}<0,05$ level: $\mathrm{F}(113 ; 89 ; 405$; $787 ; 426 ; 408 ; 377)=38,696, \mathrm{p}=0,000$. The comparison at different educational level shows a statistically significant effect at a $\mathrm{p}<0,05$ level for the cluster of responsible consumers: $\mathrm{F}(1.685 ; 698 ; 222)=12,073, \mathrm{p}=0,023$. Consumers in the responsible cluster also have a level of monthly income that is statistically higher than other clusters: $F(459 ; 756 ; 917 ; 473)=42,304, p=0,000$

Moving to the analysis of actual purchasing decisions, Table 4 presents the label classification for the 344 actually most purchased products by consumers in the responsible cluster. It allows us to understand the relevance given to social and/or environmental issues in actual purchases by responsible consumers, thus addressing the research questions of this study.

Tab. 4: Social and environmental features in most purchased products (\%)

\begin{tabular}{|l|r|r|r|r|r|r|}
\hline \multirow{2}{*}{ Labels of the product } & \multicolumn{2}{|c|}{$\begin{array}{c}\text { Most purchased } \\
\text { products }\end{array}$} & \multicolumn{2}{c|}{$\begin{array}{c}\text { Social } \\
\text { products }\end{array}$} & \multicolumn{2}{c|}{$\begin{array}{c}\text { Environmental } \\
\text { products }\end{array}$} \\
\cline { 2 - 7 } & \multicolumn{1}{|c|}{$\mathrm{n}$} & \multicolumn{1}{c|}{$\%$} & $\mathrm{~N}$ & $\%$ & $\mathrm{n}$ & $\%$ \\
\hline Label & 129 & 37,2 & 36 & 11,4 & 93 & 27,0 \\
Biological & 65 & 18,9 & - & - & 65 & 18.9 \\
Cause-related campaign & 7 & 2,0 & 7 & 2,0 & - & - \\
Responsible supply chain & 7 & 2,0 & 7 & 2,0 & - & - \\
Diet nutritional & 22 & 6,4 & 22 & 6,4 & - & - \\
Ecological packaging & 4 & 1,2 & - & - & 4 & 1,1 \\
Ecological product & 24 & 7,0 & - & - & 24 & 7,0 \\
Fair trade & 0 & 0,0 & 0 & 0,0 & - & - \\
& 215 & 62,8 & 308 & 88,6 & 251 & 73,0 \\
No label & & & & & & \\
\hline Total & 344 & 100,0 & 344 & 100,0 & 344 & 100,0 \\
\hline
\end{tabular}

Source: Authors' Own Elaborations

The first research question is on the existence of a propensity-behavior gap in the purchasing choice of responsible consumers. The analysis of the labels of the most purchased products demonstrates a significant difference between declared RCP and 
actual purchasing decisions. The majority of the most purchased products by responsible consumers are not characterized by any social or environmental label, which on the contrary is present in $37,2 \%(n=129)$ of considered products. The most important label in the most purchased products is the biological one $(18,9 \% ; n=65)$, that states that productive processes respect the (natural) environment and guarantees the absence of polluting pesticide.

The table shows that responsible consumers do not relevantly consider social features in their purchasing choices: only 36 products $(11,4 \%)$ can be considered as socially responsible products. None of the 344 most purchased products have a fair trade label. Only 7 products $(2,0 \%)$ present a label that states the existence of a cause-related marketing campaign and an equal percentage displays a label which declares that the manufacturing process is realized in the respect of human rights. A higher percentage refers to products with diet nutritional information $(6,4 \%, 22$ products).

Environmental products are the most important labeled products in the analysis, including biological, ecological packaging and ecological labeled products. This group involves $27,0 \%(n=93)$ of the most purchased products. It is mainly composed of biological labeled $(18,9 \%)$ products, while only a restricted number refers to other ecological features: 24 products present an ecological label $(7,0 \%)$, and four products present an ecological packaging label $(1,2 \%) .8,2 \%$ of the products are purchased exclusively because of their environment-friendly characteristics and they are as important as healthy products. In particular, those with a diet nutritional feature represent $6,4 \%(n=22)$ of the sample.

The second research question addresses the reasons for responsible consumption and whether customers are driven by political or self-care intentions. The purchase of healthy products is considered here as an expression of self-care rationale, while social and environmental products without a clearly healthy value are related to the political rationale. Results are presented in Table 5.

Tab. 5: Self-interest and political rationale of the most purchased products (\%)

\begin{tabular}{|l|r|r|r|r|}
\hline \multirow{2}{*}{ Labels of the product } & \multicolumn{2}{|c|}{ Self-Interest } & \multicolumn{2}{c|}{ Political interest } \\
\cline { 2 - 5 } & $\mathrm{n}$ & \multicolumn{1}{c|}{$\%$} & $\mathrm{n}$ & \multicolumn{1}{c|}{$\%$} \\
\hline Label & 87 & 25,3 & 42 & 12,2 \\
Biological & 65 & 18,9 & & \\
Cause-related campaign & - & - & 7 & 2,0 \\
Responsible supply chain & - & - & 7 & 2,0 \\
Diet nutritional & 22 & 6,4 & - & - \\
Ecological packaging & - & - & 4 & 1,2 \\
Ecological product & - & - & 24 & 7,0 \\
Fair trade & - & - & 0 & 0,0 \\
& & & & \\
No label & 257 & 74,7 & 302 & 87,8 \\
& & & & \\
\hline Total & 344 & 100,0 & 344 & 100,0 \\
\hline
\end{tabular}

Source: Authors' Own Elaborations 
The analysis shows that there is a difference between the two rationales behind responsible purchasing choices. In fact, $25,3 \%$ of labeled products are related to self-interest expression and $12,2 \%$ are the expression of political rationale. At the same time the results suggest that, social interest is less relevant than environmental interest within the group of products related to the political rationale, since only 14 products HAVE a social label, while 28 possess an ecological one.

\section{Discussion of results}

The study addressed the relationship between the RCP-behavior gap in real settings and the rationales that may influence the gap. Indeed, the study overcame some of the major limitations in previous research and contributed to the understanding of the gap. Notwithstanding these relevant contributions, it is useful to highlight some limitations. First, the research is limited in scope, as it only included Italian consumers in the sample. Other academics could fix this limitation by conducting further similar research in other countries, so as to highlight whether the relationship between socio-demographical characteristics and RCP are affected by national contexts or religious traditions, since they might influence the importance given to specific social/environmental attributes. Second, the study didn't evaluate the effects of traditional criteria (such as price, quality and availability) on the importance consumers give to the social and environmental attributes of products. This calls for additional studies that embed traditional features of the products as control variables in the analysis. Third, the study doesn't completely evaluate the effect of a consumer's life on their purchasing processes. Further work could address the differences in RCP along a consumer's life, therefore contributing to understanding how RCP-behavior evolves with regards to variables that were not taken into consideration in the present study, such as family composition and job position.

Although the limitations of the study reduce the generalizability of its results, the existence of a RCP-behavior gap pointed out by previous studies is further supported by the present research. Since the survey was conducted in real settings, it is reasonable to say that the existence of such a dichotomy is not determined by difficulties in survey methodologies of extant researches carried out in simplified or ad-hoc contexts, but it does effectively shape the market of socially and/or environmentally responsible products.

It is possible to say that when performing their purchasing decisions consumers are driven by product characteristics rather than personal values and believes (Follows and Jobber, 2000). In this sense, it does not seem reasonable to expect a trade-off between traditional criteria and social and environmental ones. On the contrary, consumers mainly buy products that respond to the increasing attention towards these issues, in cases of the same level in price, quality and availability of products. 
A different pattern of behavior emerges for socially and environmentally oriented products. By comparing products with social and environmental labels, the analysis has shown that responsible consumers mainly prefer environmentally responsible products, while they tend not to purchase those characterized by a strict social orientation. Therefore, the RCP-behavior gap is more consistent when referred to social labels.

In the light of these considerations, while socially oriented products should be devoted to a focused group of consumers, environmental ones can reach a larger market. Though the research was not devoted to exploring the reasons behind the different behavior, which represents an interesting objective for future studies, a valid explanation can be found in the different capability of consumers to identify and evaluate social issues in a product life cycle. Indeed, if environmental issues can be recognized during product usage and disposal - more often related to reduced emission, pollution or waste - social aspects can only be appreciated through the information provided by producer.

The different behavior towards social and environmental products can be further explained by looking at the rationale behind responsible choices of consumption. Moving to the second research question, results have underlined that the most purchased products are labeled as biological. These products are characterized by their respect of natural environment throughout their productive processes as they exclude the use of dangerous substances that are risky for personal health. Products without a clear advantage for personal health represent a significant lower share.

Results highlight that responsible consumers base their purchasing decisions on a twofold criterion, since the evaluation of the environmental value of a product is strictly related to that of potential benefits for their own health and safety. The limited presence of products characterized by exclusive environmental values or related to specific social concerns supports this proposition and confirms that selfcare considerations overcome political ones.

On the managerial side, these results suggest three main implications. First, as socio-demographic variables allow the identification of groups of customers who will be more likely to prefer a socially and/or environmentally responsible product, they are valuable for their use by managers in their segmentation of the market. In this manner, managers could find generalizable indications on how to segment the market and define the positioning strategy and thus have a lever on the higher sensitiveness of customers with a higher RCP.

Second, products with pure social or environmental content represent a very limited portion of the purchasing choices of responsible consumers. Managers should therefore be aware that such products mainly target a niche in the market that is generally represented by well-informed consumers. In this case, social or environmental characteristics are aimed at giving consumers an intrinsic added value that responds to their request for higher corporate responsibility.

The higher complexity of product characteristics determined by the integration of social or environmental dimensions calls for better communication (Drumwright, 1996). Corporate efforts should therefore be dedicated to increasing consumers' 
knowledge about the social and environmental performance of productive processes, thus leveraging their sensitiveness and commitment to social or environmental causes. These considerations suggest that socially responsible products require a higher degree of trust between producer and consumer in order to affect consumers' purchasing decisions (Megicks et al. 2008).

In this sense, companies that want to differentiate themselves based on social contents should develop consumers' knowledge around the social implications of their productive processes, so as to increase their awareness towards such considerations (De Pelsmacker et al., 2005).

Therefore, it is of primary importance for marketers to advertise why it is convenient to purchase social and environmentally oriented products. More and more companies educate consumers about the convenience of buying ecologically safe products. The education of the consumer is seen as an appropriate method for increasing perceived convenience related to social and environmentally oriented products.

Finally, if managers want to target a larger share of the market, they should develop products that make good use of social/environmental characteristics to enhance performance related to traditional attributes. Moreover, they should develop marketing activities aimed at facilitating consumers in the recognition of related advantages (Megicks et al., 2008).

This is particularly true for environmentally responsible products, whose content affect the actual responsible consumers' choices more strongly when related to selfcare advantages. In this sense it might be useful to develop dedicated brands (Nicholls and Lee, 2006), capable of attracting consumers' attention towards the specific benefits determined about by the integration of social and environmental dimensions.

As a result, alternative marketers may allocate responsible products for a specific target and advertise their new line of social or environmental products accordingly. The possibility to alternatively adjust responsible products for a large share of the market or a specific niche opens the opportunity to successfully create different strategies to marketers. 
Tab. 6: The Post-Hoc Tukey HSD Test by Age

\begin{tabular}{|c|c|c|c|}
\hline \multirow{2}{*}{$\begin{array}{r}\text { Age } \\
(\mathrm{A})\end{array}$} & \multirow{2}{*}{$\begin{array}{c}\text { Age } \\
\text { (B) }\end{array}$} & \multicolumn{2}{|c|}{$\begin{array}{l}\text { Mean difference } \\
(A-B)\end{array}$} \\
\hline & & -0.113 & ** \\
\hline & $25-34$ & -0.221 & ** \\
\hline & $35-44$ & -0.266 & ** \\
\hline & $45-54$ & -0.293 & ** \\
\hline & $55-64$ & -0.267 & ** \\
\hline & $>65$ & -0.229 & $\star \star$ \\
\hline $20-24$ & $14-19$ & 0.112 & $\star \star$ \\
\hline & $25-34$ & -0.109 & $* *$ \\
\hline & $35-44$ & -0.154 & ** \\
\hline & $45-54$ & -0.180 & ** \\
\hline & $55-64$ & -0.155 & ** \\
\hline & $>65$ & $-0,116$ & ** \\
\hline $25-34$ & $14-19$ & 0.221 & $\star \star$ \\
\hline & $20-24$ & 0.109 & $* *$ \\
\hline & $35-44$ & -0.045 & * \\
\hline & $45-54$ & -0.072 & ** \\
\hline & $55-64$ & -0.046 & * \\
\hline & $>65$ & -0.008 & \\
\hline $35-44$ & $14-19$ & 0.266 & ** \\
\hline & 20-24 & 0.154 & ** \\
\hline & $25-34$ & 0.045 & * \\
\hline & $45-54$ & -0.026 & \\
\hline & $55-64$ & -0.001 & \\
\hline & $>65$ & 0.038 & \\
\hline $45-54$ & $14-19$ & 0.293 & ** \\
\hline & $20-24$ & 0.180 & ** \\
\hline & $25-34$ & 0.072 & $\star \star$ \\
\hline & $35-44$ & 0.026 & \\
\hline & $55-64$ & 0.025 & \\
\hline & $>65$ & 0.064 & $\star *$ \\
\hline $55-64$ & $14-19$ & 0.267 & ** \\
\hline & $20-24$ & 0.155 & ** \\
\hline & $25-34$ & 0.046 & * \\
\hline & $35-44$ & 0.001 & ** \\
\hline & $45-54$ & -0.025 & \\
\hline & $>65$ & 0.039 & \\
\hline$>65$ & $14-19$ & 0.229 & ** \\
\hline & $20-24$ & 0.116 & ** \\
\hline & $25-34$ & 0.008 & \\
\hline & $35-44$ & -0.038 & \\
\hline & $45-54$ & -0.064 & $\star \star$ \\
\hline & $55-64$ & -0.039 & \\
\hline
\end{tabular}

Source: Authors' Own Elaborations 
Tab. 7: The Post-Hoc Tukey HSD Test by Income

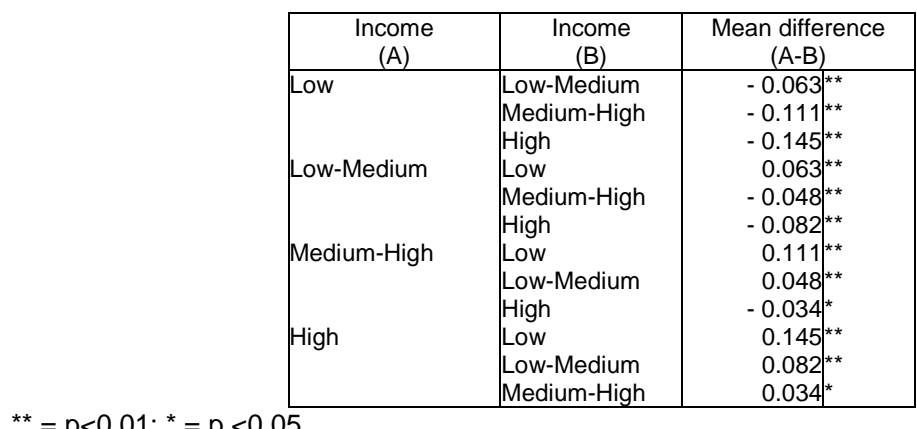

Source: Authors' Own Elaborations

Tab. 8: The Post-Hoc Tukey HSD Test by Educational Level

\begin{tabular}{|c|c|c|}
\hline \begin{tabular}{|c}
$\begin{array}{c}\text { Educational level } \\
(\mathrm{A})\end{array}$ \\
\end{tabular} & $\begin{array}{c}\text { Educational level } \\
\text { (B) }\end{array}$ & $\begin{array}{c}\text { Mean difference } \\
(\mathrm{A}-\mathrm{B})\end{array}$ \\
\hline $\begin{array}{l}\text { Minimum level } \\
\text { High school } \\
\text { Graduate }\end{array}$ & $\begin{array}{l}\text { High school } \\
\text { Graduate } \\
\text { Minimum level } \\
\text { Graduate } \\
\text { Minimum level } \\
\text { High school } \\
\end{array}$ & $\begin{array}{r}-0.0711^{\star \star} \\
-0.1399^{\star *} \\
0.0711^{\star \star} \\
-0.1399^{\star *} \\
0.210 \\
0.139{ }^{\star \star}\end{array}$ \\
\hline
\end{tabular}

Source: Authors' Own Elaborations

\section{References}

ANDERSON T. JR, CUNNINGHAM W.H. (1972), "The socially conscious consumer", Journal of Marketing, vol. 36, n. 7, pp. 23-31.

HUNT S.D., VITELL S. (1986), "A General Theory of Marketing Ethics", Journal of Macromarketing, vol. 6, n. 1, pp.5-16.

ARNOLD M.J., REYNOLDS K. (2003), "Hedonic Shopping Motivations", Journal of Retailing, vol. 9, n. 2, pp. 77-95.

BENNET L. (2004), "Branded Political Communication: Lifestyle Politics, Logo Campaigns, and the Rise of Global Citizenship", Politics, Products, and Markets: Exploring Political Consumersims Past and Present, eds. Micheletti M, Follesdal A., Stolle D. Transaction Publisher: New Brunswick, NJ.

BJØRNER T.B., HANSEN L.G., RUSSELL C.S. (2004), "Environmental labeling and consumers choice - an empirical analysis of the effect of the Nordic Swan", Journal of Environmental Economics and Management, vol. 47, n. 3, pp. 411-434.

BRODY A.L., MARSH K.S. (1997), In The Wiley Encyclopedia of Packaging Technology, 2nd ed, John Wiley and Sons, New York.

BROWN T., DACIN P. (1997), "The Company and the Product: Corporate Associations and Consumer Product Responses", Journal of Marketing, vol. 61, n. 1, pp. 68-84. 
CARTER C.R., DALE R.S. (2008), “A framework of sustainable supply chain management. moving towards new theory", International Journal of Physical Distribution and Logistics Management, vol. 38, n. 5, pp. 360-387.

CARUANA R. (2007), "Morality and consumption: towards a multidisciplinary perspective", Journal of Marketing Management, vol. 23, n. 3-4, pp. 207-225.

CASELLI L. (2005), "La responsabilità sociale dell'impresa tra democrazia e mercato", Sinergie, n. 67, pp. 46-53.

COHEN J.W. (1988), Statistical Power Analysis for the Behavioral Sciences. 2nd edition, Lawrence Erlbaum Associates: New Jersey.

DE PELSMACKER P., DRIESEN L., RAYP G. (2005), "Do Consumers Care about Ethics? Willingness to Pay for Fair-Trade Coffee", Journal of Consumer Affairs, vol. 39, n. 2, pp. 363-385.

DE PELSMACKER P., JANSSENS W., STERCKX E., MIELANTS C. (2004), "Consumer preferences for the marketing of ethically labelled coffee", International Marketing Review, vol. 22, n. 5, pp. 512-530.

DINITTO E. (1989), "Marketing With a Conscience”, Marketing Communications, vol. 14, n. 5, pp. 42-46.

DRUMWRIGHT M.E. (1996), "Company Advertising with a Social Dimension: the Role of Noneconomic Criteria”, Journal of Marketing, vol. 60, n. 4, pp. 71-87.

ENGEL J.F., BLACKWELL R.D. (1982), Consumer Behaviour, The Dryden Press, New York, NY.

FOLLOWS S.B., JOBBER D. (2000), "Environmentally Responsible Purchase Behaviour: A Test of Consumer Model”, European Journal of Marketing, vol. 34, n. 5/6, pp. 723 746.

FULLER D.A. (1999), Sustainable Marketing: Managerial-Ecological Issues, Sage Publications, Thousand Oaks, CA.

GABRIEL Y., LANG T. (1995), The Unmanageable Consumer, Sage, London.

GARRETT D. (1987), "The Effectiveness of Marketing Policy Boycotts: Environmental Opposition to Marketing", The Journal of Marketing, vol. 51, n. 2, pp. 46-57.

GOLDSMITH E., MANDER J. (1996), The Case Against the Global Economy, Sierra Club: San Francisco.

GORSUCH R.L. (1983), Factor analysis ( $2^{\text {nd }}$ ed), Lawrence Erlbaum Associates: Hillsdale.

HAIR J., BLACK W., BABIN B., ANDERSO R., AND TATHAM R. (2006), Multivariate data analysis (6th ed.), Pearson Prentice Hall, Uppersaddle River.

HAIR J.F., BLACK W.C. (2000), "Cluster Analysis" in Laurence G. Grimm and Paul R. Yarnold Eds., Reading and Understanding More Multivariate Statistics, American Psychological Association: Washington.

HUNT S.D., VITELL S. (1986), "A general theory of marketing ethics", Journal of Macromarketing, vol. 6, n. 1, pp. 5-16

ISTAT (2009), Bilancio Demografico 2008, Istat: Roma.

KLOPP P., MCDONALD M. (1981), "Nutrition labels: an exploratory study of consumer reasons for nonuse", Journal of Consumer Affairs, vol. 15, n. 2, pp. 301-16.

KRIER J.M. (2007), Fair Trade 2007: new facts and figures from an ongoing success story. A report on Fair Trade in 33 consumer countries, Brussels: Fair Trade Advocacy Office.

LOCKE R.M. (2003), "The promise and perils of globalization: The case of Nike", in Kochan TA, Schmalensee RL Ed., Management: Inventing and delivering its future, pp. 3970. Cambridge and London: MIT Press.

MALHOTRA N.K. (1996), Marketing Research: An Applied Orientation, 2nd ed, Englewood Cliffs: Prentice-Hall. 
MCDONALD S., OATES C., YOUNG C.W., HWANG K. (2006), “Toward sustainable consumption: Researching voluntary simplifiers", Psychology and Marketing, vol. 23, n. 6, p. 515-534.

MCGREGOR S. (2006), "Understanding consumers moral consciousness", International Journal of Consumer Studies, vol. 30, n. 2, pp. 164-178.

MEGICKS P., MEMERY J., WILLIAMS J. (2008), "Influences on ethical and socially responsible shopping: evidence from the UK grocery sector", Journal of Marketing Management, vol. 24, n. 5-6, pp. 637-659.

MENON A., MENON A. (1997), "Enviropreneurial marketing strategy: the emergence of corporate environmentalism as market strategy", Journal of Marketing, vol. 61, n. 1, pp. 51-67.

MICHELETTI M., FOLLESDAL A., STOLLE D. (2003), Politics, products, and markets: Exploring political consumerism past and present, Transaction Press: New Brunswick, NJ.

MICHELETTI M., STOLLE D. (2005), “The Concept of Political Consumerism”. Youth Activism-An International Encyclopedia, ed. L. R. Sherrod, Greenwood Publishing: Wesatport.

MICHELETTI M., STOLLE D. (2009), "Consumers as Political Actors. in Critical Food Issues: Problems \& State-of-the-Art Solutions, eds. Lynn Walter and Laurel E. Phoenix. Westport, Connecticut: Greenwood Publishing Group, pp. 188-214.

MOHR L.A., WEBB D.J., HARRIS K.E. (2001), "Do Consumers Expect Companies to be Socially Responsible? The impact of Corporate Social Responsibility on Buying Behavior", Journal of Consumer Affairs, vol. 35, n. 1, pp. 45-72.

MOORMAN C., MATULICH E. (1993), "A model of consumers' preventive health behaviour: the role of health motivation and health ability", Journal Consumer Research, vol. 20, n. 2, pp. 208-228.

NEBENZAHL I.D., JAFFE E.D. AND KAVAK B. (2001), "Consumers' Punishment and Rewarding Process via Purchasing Behavior", Teaching Business Ethics, vol. 5, n. 3, p. 283-305.

NEWHOLM T., SHAW D. (2007), "Studying the ethical consumer: a review of research", Journal of Consumer Behaviour, vol. 6, n. 5, pp. 253-270.

NICHOLLS A.J. (2004), "Fair Trade New Product Development", Service industries Journal, vol. 24 , n. 2, pp. 102-177.

NICHOLLS A.J., LEE N. (2006), "Purchase decision-making in fair trade and the ethical purchase 'gap': 'is there a fair trade twix?", Journal of Strategic Marketing, vol. 14, n. 4, pp. 369-386.

PAGE G., FEARN H. (2005), "Corporate reputation: What do consumers really care about?", Journal of Advertising Research, vol. 45, n. 3, pp. 305-313.

PASCUCCI F. (2011), "Responsabilità sociale e questione etica nell'impresa: alcune riflessioni”, Sinergie, n. 86, pp. 133-150.

PEATTIE K. (1995), Environmental Marketing Management: Meeting the Green Challenge, Pitman Publishing Company, London, UK.

PEDRINI M., FERRI L.M., (2014), "Socio-demographical antecedents of responsible consumerism propensity", International Journal of Consumer Studies, vol. 38, n. 2, pp. 127-138, DOI: 10.1111/ijcs.12074.

PERRINI F., TENCATI A. (2008), "La responsabilità sociale d'impresa: strategia per l'impresa relazionale e innovazione per la sostenibilità", Sinergie, n. 77, pp. 23-43.

POL L.G. (1986), "Marketing And The Demographic Perspective", Journal of Consumer Marketing, vol. 3, n. 1, pp. 57-65. 
PROTHERO A. (1990), "Green consumerism and the societal marketing concept- marketing strategies for the 1990s", Journal of Marketing Management, vol. 6, n. 2, pp. 87-103.

PUNJ G.N., STEWART D.W. (1983), "Cluster Analysis in Marketing Research: Review and Suggestions for Application”, Journal of Marketing Research, vol. 20, n. 2, pp. 134148.

ROBERTS J.A. (1995), "Profiling levels of socially responsible consumer behavior: a cluster analytic approach and its implications for marketing", Journal of Marketing Theory and Practice, vol. 3, n. 4, pp. 97-117.

ROBERTS J.A. (1996), "Green consumers in the 1990s: profile and implications for advertising", Journal of Business Research, vol. 36, n. 3, pp. 217-231.

RODE J., HOGARTH R.M., LE MENESTREL M. (2008), "Ethical differentiation and market behaviour: An experimental approach", Journal of Economic Behaviour and Organization, vol. 66, n. 2, pp. 265-280.

SCHLEGELMILCH B.B., BOHLEN G.M., FIAMANTOPULOS A. (1996), "The link between green purchasing decisions and measures of environmental consciousness", European Journal of Marketing, vol. 30, n. 5, pp. 35-55.

SCHLEGELMILCH B.B., BOHLEN G.M., DIAMANTOPOULOS A. (1996), "The link between green purchasing decisions and measures of environmental consciousness", European Journal of Marketing, vol. 30, n. 5, pp. 35-55.

SCIARELLI S. (2005), "L'ampliamento della responsabilità sociale dell'impresa", Sinergie, n. 67 , p. $36-43$.

SHAW D., NEWHOLM T. (2002), "Voluntary simplicity and the ethics of consumption", Psychology and Marketing, vol. 19, n. 2, pp. 167-185.

STEENHAUT S., VAN KENHOVE P. (2006), "An Empirical Investigation of the Relationships among a Consumer's Personal Values, Ethical Ideology and Ethical Beliefs", Journal of Business Ethics, vol. 64, n. 2, pp. 137-155.

STRAUGHAN R.D., ROBERTS J.A. (1999), "Environmental segmentation alternatives: a look at green consumer behavior in the new millennium", Journal of Consumer Marketing, vol. 16, n.6, p. 558-575.

STRONG C. (1996), "Features contributing to the growth of ethical consumerism", Marketing Intelligence and Planning, vol. 14, n. 5, pp. 5-13.

TABACHNICK B.G., FIDELL L.S. (2008), Using multivariate statistics $5^{\text {th }}$ edition, Pearson education, Boston.

UUISATALO O., OKSANEN R. (2004), "Ethical Consumerism: a View from Finland", International Journal of Consumer Studies, vol. 28, n. 3, pp. 214-222.

VANDERMERWE S., OLIFFE M.D. (1990), “Customers drive corporations green”, Long Range Planning, vol. 23, n. 6, pp. 10-16.

VARUL M.Z., WILSON-KOVACS D. (2008), Fair Trade Consumerism as an Everyday Ethical Practice - A Comparative Perspective, University of Exeter and ESRC.

VITELL S.J. (2003), "Consumer Ethics Research: Review, Synthesis and Suggestions for the Future", Journal of Business Ethics, vol. 43, n. 1-2, pp. 33-47.

WAGNER A.S. (1997). Understanding Green Consumer Behavior: A Qualitative Cognitive Approach, Routledge, New York.

WEBSTER F.E. (1975), "Determining the characteristics of socially conscious consumer", Journal of Consumer Research, vol. 2, n. 2, pp. 188-196.

WEST K. (1995), "Ecolabels: the industrialisation of environmental standards", The Ecologist, vol. 25, n. 1, pp. 16-21. 
